\title{
Price-quality Dimensions of Organizational Buying Behaviour in Cross River State, Nigeria
}

\author{
Ezekiel Tom Ebitu ${ }^{1}$, Eyo Emmanuel Essien ${ }^{1} \&$ Glory Basil $^{1}$ \\ ${ }^{1}$ Department of Marketing, University of Calabar, Calabar, Nigeria \\ Correspondence: Eyo Emmanuel Essien, Department of Marketing, University of Calabar, Calabar, Nigeria. Tel: \\ 234-803-320-6386. E-mail: ecubed2006@yahoo.com
}

\author{
Received: March 13, 2012 Accepted: May 21, 2012 Online Published: July 25, 2012 \\ doi:10.5539/ijms.v4n4p78 URL: http://dx.doi.org/10.5539/ijms.v4n4p78
}

\begin{abstract}
This study examined the roles of price differentials offered by industrial goods vendors and quality specifications for industrial products in determining organizational buyer decision to patronize one vendor rather than another. Using survey data generated from 321 respondents in the three categories of business consumers in the Southern Senatorial district of Cross River State, our hypotheses were supported. Results of data analysis show that price differentials and quality requirements for industrial product significantly influence organizational buying behaviour. Our findings also suggest that because price differential are perceived by the customers as a gauge of value and quality, marketing managers of industrial goods and services stand to gain more by adopting strategies which give special attention to the ways buyers trade-off costs and benefits of various products.
\end{abstract}

Keywords: price differentials, quality requirements, organizational buying behaviour

\section{Introduction}

Organizational buying behaviour has been shown to be significantly different from that of the ultimate consumer (Hutt and Speh, 1998, Ekerete, 2005; Agbonifoh, et al., 2007). Consequently, the motives for organizational buying differ from those for consumer buying and because of the differences in buying motive, the factors or determinants of organizational buying as well as the marketing strategies designed for business marketing are different from those of ultimate consumers.

The organizational buyer is influenced by a wide array of forces inside and outside the organization, and unlike the ultimate consumer, the organizational buyer is largely rational in his choice and motivated by budgetary considerations such as profit goals, expense quotas, and cost benefit guidelines. The organizational buyer must be prepared to justify his purchases on the basis of measurable performance. Consequently, the variables which influence the professional buyer's decision to patronize one industrial product vendor/supplier rather than another tend to be quality, service and price-frequently in that order. These are not the only variable weighed by industrial goods purchaser, but according to Webster (1970), they are the most common ones.

Although the supplier's quality and price of offerings - along with other considerations are typically evaluated by the buying organization as a package with the possibility of trade-offs, this paper considers them separately and examines how they influence organization buying behaviour.

\section{Statement of Problem}

Over the years, theorists and practitioners of business marketing management have tried to provide the marketing manager with a conceptual framework within which to analyze their customers and thus be able to tailor their products/services and communication to reach the appropriate audience. Equally, several studies have resulted in models that explain the factors influencing purchasing decisions or organizational buyers. Unfortunately however, these studies and the models derived from them, tend to be limited, at least, for one significant reason. Most of the studies are concerned with behaviour of organizational buyers in developed and industrialized economics. According to Agbonifoh, et al., (2007), the rather low level of industrialization and purchase of industrial goods in Nigeria makes it difficult to appreciate the need for the separate treatment of industrial marketing. Unlike in most developed and competitive economics where the organizational buyer must justify his decisions on the basis of measurable performance, the legal requirement of "local content", the pervasive problem of corruption and "man-know-man", etc. may influence how organizations buy in Cross River 
State. For example, Hambagda (1985) in his study of the buying process in the public sector of Nigeria concluded that inducement significantly determine who is patronized.

It is against this backdrop that we propose to investigate whether price differentials offered by vendors and quality requirements of industrial products significantly determine choice decisions of organizational buyers to patronize one vendor rather than another.

\section{Theoretical Framework}

\subsection{The Meaning of Quality of Industrial Goods/Services}

The ever-increasing quality specification from customers of industrial goods/services because of the impact poor quality has on the firm is a very critical issue in organizational buying today. For every buying organization, choosing the right level of quality is an important element in the purchasing function, because, according to Dwyer and Tanner Jr. (2002), quality impacts manufacturing and marketing in both cost and potential contribution.

Quality is ultimately defined by the consumer. Quality, among other variables, serves as the consideration which influence the professional buyer's decision to patronize one supplier rather than another (Webster, 1970). A professional buyer tends to define product quality as the combination of properties which fit the product to intended use. The buyer wants these properties to be present in the product in precisely the degree needed to suit its purpose and no more. Studies have also shown that most large organizations are as reluctant to pay for extra quality (over and above a reasonable safety factor that it does not need) as it is to buy goods of inferior quality. In other words, though higher quality can mean a higher cost for the product, it does not necessarily mean better quality (Richeson, et al., 1995).

Ekerete (2005) describe a quality product as one which enhances the life expectancy of another product with which it is used, or otherwise increase the value of the finished product to the ultimate buyer. According to him, another consideration inseparably related to quality requirement of industrial product is the supplier's ability to deliver materials, components and supplies of consistent quality.

Assumed consistency of quality can reduce the need for meticulous and costly inspections and testing of incoming supplies. It also does much to assume that the end product would be of uniform quality (Ekerete, 2005, Richeson, et al., 1995). For the manufacturing firms, Ekerete (2005) also observed that consistency of quality diminishes shutdown time and repair costs for delicate machines unable to handle materials of varying quality without adjustments, or machines that may be damaged by imperfections in the materials processed on them.

The amount or degree of quality needed by a customer as well as the range of tolerance in standards can usually be determined by a study of the customer's production system or other operating system. This process is described as Quality Function Development (QFD) (Dwyer and Tanner, 2002). According to them, because of the importance of quality requirement/specification for industrial goods, organizations now use QFD to represent how suppliers and customers work together to create value by linking customer needs and product attributes.

\subsection{Price of Industrial Product}

Price here is viewed from the perspective of the buyer (that is, as a determinant of organizational buyer behaviour) rather than from the perspective of the industrial goods vendor or supplier. The price that business marketers assign to a product or service, according to Hutt and Speh (1998) is one of the many factors scrutinized by the organizational buyer. The importance of obtaining the right price was highlighted by Lanani (2005) when he observed that pricing decision is central to the organization's business plan because it affect the critical aspect of the organization's marketing strategy. When members of a buying centre select a particular product, they are buying a given level of product quality, technical services and delivery reliability. This means that when considering the cost or price to pay for a product, organizational buyers look beyond the quoted price of the supplier and rather consider the attribute bundles being offered. Wilson (1986) categorized these attributes into three: product-specific attributes (example, product quality); company related attributes (example, reputation for technological excellence); and sales-person related attributes (example, dependability).

Also, Shapiro and Jackson (1978) observed that the cost of an industrial good include much more than the seller's price and that pricing decision and product policy decisions are inseparable, and must be balanced within the firm's market segmentation plan.

When purchasing a product, an organizational customer always assumes various cost above and beyond the actual purchase price. This price has been described as evaluated price by Ekerete (2005) and total cost by Wilson (1986). According to Ekerete (2005) the evaluated price (rather than the supplier's quoted price) takes 
into consideration a variety of factors such as the amount of scrap or waste resulting from the use of materials, the cost of handling and processing the material/product, the amount of power it consumes, loss or damage liability, and a host of other variables that generate or minimize cost-in-use.

For example, an Indian or Chinese made truck may have a lower quoted price compared to a Japanese truck, but very expensive to maintain due to the unavailability of spare parts and local technicians to service it. Equally, the patronage of local suppliers in keeping with government's "local content" policy may be costlier (in terms of training and re-training) than foreign suppliers, but the long-term gain in terms of development of local manpower and the local economy may be far more beneficial to the nation and organization.

Two competitors with similar products may ask differing prices because, as observed by Hutt and Speh (1998) their total offering are perceived (evaluated) as being unique by buyer. In the eyes of the organizational buyer, one firm may provide more value than the other. For this reason, organizations consider and evaluate these factors in deciding what price to pay (Ekerete, 2005).

\section{Research Methodology}

The two hypotheses this study tested are:

i. $\mathrm{H}_{0}$ : There is no significant relationship between organizational buying decision and quality requirement of industrial goods.

ii. $\mathrm{H}_{0}$ : Price differential is not a significant fact in organizational buying.

This study is based on the buying behaviour of organizational buyers or consumers. Organizational consumers are categorized into three (Hutt and Speh): Government Consumers (Federal, State and Local Government, including their Agencies and Parastatals); commercial enterprises, and institutional consumers (non-profit organizations, churches, etc). These categories constituted the population from which the sample was drawn.

The sample size was determined using the method below (Collins, 1986):

$$
\left.n=z^{2}[(1+0.02)(b-1)\}\right] \times p q E^{2}
$$

Where $\mathrm{n}$ is the sample size, $\mathrm{z}$ is the significance level (assumed to be $95 \%$ ), $\mathrm{b}$ is the stage of sampling and $\mathrm{p}$ is the estimate of expected population proportion having desired characteristics based on prior information, $q$ (or 1 $-p$ ) is the estimate of expected population not having the characteristics of interest; and $E$ is the estimated error margin (assumed to be 5\%). In a pilot survey of fifteen persons in three organizations by the researchers, nine (9) persons interviewed indicated that the variables outlined in the pilot survey instrument are strongly considered when deciding to buy. A strong positive response of nine (9) out of fifteen (15) equals 60 percent. Out $p$ - value was therefore taken as $60 \%$. If $b=1$, then

$$
\begin{gathered}
n=\left(z^{2} p q\right) / E^{2} \\
n=1.96^{2} * 0.6 * 0.4 / 0.05^{2}=369
\end{gathered}
$$

The study is cross - sectional in design and was conducted using self-administered questionnaires. Out of the 369 questionnaires distributed to respondents only 321 of the returned copies were properly filled out and used for the study. This represents a response rate of $86 \%$. The sample comprise respondents drawn from three local government areas of Cross River State: Calabar Municipal, Odukpani and Akamkpa. Questionnaires were distributed only to organizational members who had direct role in the buying process. In the survey we employed several methods to ensure that the informants were appropriate and competent to answer or respond to the enquiries. First, $72.6 \%$ of the informants/respondents were managers, unit heads, senior staff, or officers directly involved in buying decision or the selection of suppliers. The average length of time of the respondent being in such a position of responsibility (i.e., years of knowledge and experience) was 3.6 years.

All measures made use of five-point Likert scale and were adapted from extant literature. Although the data collection instrument was designed along multiple -items format the single item approach was used to measure the constructs being studied.

\section{Results and Discussions}

The first hypothesis asserted the nature of the relationship between quality requirements of industrial products and organizational buying decision. Table 1 shows the result of correlation test between quality requirements and organizational buying behaviour. 
Table 1 . The result of correlation test between quality requirements and organizational buying behaviour

\begin{tabular}{|c|c|c|c|c|c|c|}
\hline Variables & $\begin{array}{l}\Sigma \mathrm{x} \\
\sum \mathrm{y}\end{array}$ & $\begin{array}{l}\Sigma \mathrm{x}^{2} \\
\Sigma \mathrm{y}^{2}\end{array}$ & $\Sigma x y$ & $r$ & zcal & zcrit \\
\hline Quality requirements $(\mathrm{x})$ & 321 & 39,295 & & & & \\
\hline Organizational buying behaviour (y) & 321 & 23,817 & 15,488 & 0.50 & 8.94 & 1.96 \\
\hline
\end{tabular}

Source: Data Analysis, 2010

Note: Correlation is significant at 0.05 level

Statistical analysis shows that there is a positive relationship between quality requirements for industrial product and organizational choice of vendors or suppliers. However, the coefficient of correlation $\left(r^{2}=0.25\right)$ indicate that only 25 per cent of the variation in organizational buying decision could be explained. This shows that product quality is a necessary, but not a sufficient factor in predicting organizational buying decision. Moreover, the result supports the hypothesis that quality specification for industrial products is a significant factor in organizational decision to patronize one industrial goods vendor/supplier rather than another.

The important of quality specifications to the industrial consumer, according to Hutt and Speh (1998) can be seen in the increasing adoption of Quality Function Development (QFD) methods where organizations identify critical customer attributes and then establish specific links between customer attributes and product design attributes. Dwyer and Tanner Jr. (2002) asserted that quality impacts manufacturing and marketing in both cost and potential returns. The result also supports Ekerete (2005) when he pointed out that industrial buyers may pay for a qualitative product regardless of the price. Moreso, the study by Qualls and Rosa (1995) suggest that quality specification for industrial product is demanded by all forms of industrial consumers, even though what is perceive as quality defer from organization to organization and across the functional areas of administration.

Table 2 presents the summary of data analysis and correlation test to determine the significance of the relationship between price differentials being offered by industrial product vendors and organizational decision to patronize one vendor rather than another.

Table 2. The summary of data analysis and correlation test

\begin{tabular}{|c|c|c|c|c|c|c|}
\hline Variables & $\begin{array}{l}\Sigma \mathrm{x} \\
\Sigma \mathrm{y}\end{array}$ & $\begin{array}{l}\Sigma \mathrm{x}^{2} \\
\Sigma \mathrm{y}^{2}\end{array}$ & $\Sigma x y$ & $\mathrm{r}$ & zcal & zcrit \\
\hline Price differentials $(\mathrm{x})$ & 321 & 33,601 & 17,786 & 0.75 & 13.42 & 1.96 \\
\hline Organizational buying behaviour (y) & 321 & 23,817 & & & & \\
\hline
\end{tabular}

Correlation is significant at 0.05 level $(2-$ tailed $)$.

Correlation coefficient of 0.75 supports the hypothesis that there is a direct positive relationship between price and organizational buying decision. The high coefficient of determination $\left(\mathrm{r}^{2}=0.56\right)$ also indicate that the co-variation between price and organizational buying behaviour could be explained or attributed to changes in the former. This finding is supported by many studies in extant literature about the relationship of pricing of industrial goods and organizational buying decision. Shapiro and Jackson (1978) showed that organizational decision on product and price are inseparable. Price differentials offered by suppliers of industrial products translate to the perception by organizational buyers that product offerings are unique (Hutt \& Speh, 1998; Kortge $\&$ Okonkwo, 1993). Price differential offered by industrial goods vendor is also used as a gauge of value-in-use for industrial product (Ekerete, 2005; Nagle, 1987; Wilson, 1986).

\section{Conclusion and Recommendations}

The hypotheses formulated for this study were strongly supported by result of data analysis. The study provided evidence for the direct effect of price differentials and quality specification on organizational buying behaviour as suggested by literature. However, price differential seem to have a stronger influence on organizational buying decision than quality specification for industrial products. This may be because when an organization 
selects a particular product and is willing to pay for it, it is in essence, buying a given level of product quality, technical services and delivery reliability.

Price is one of the important costs that buyers examine in the buying process. Thus the marketer can profit by adopting strong end-user focus that gives special attention to the way buyers trade off the cost and benefits of various products.

A marketer's effectiveness can be a source of competitive advantage to the firm. A marketing manager's responsibility is to provide an adequate supply of the right product or service quality at the best possible price. And since quality is ultimately defined by the consumer, marketing managers have to work closely with buying organizations to ensure that the proper qualities of products are purchased.

\section{References}

Agbonifoh, B. A., Ogwo O. E., Nnolim, D. A., \& Nkamneme, A. D. (2007). Marketing in Nigeria: Concepts principles and decision (2nd ed.). Aba: Afritowers.

Collins, W. (1986). Sampling. In R. Worcester \& J. Downham (Eds.), Consumer market research handbook. London: McGraw-Hill.

Dwyer, F. R., \& Tanner, Jr, J. F. (2002). Business marketing: Connecting strategy, relationship and learning (2nd ed.). New York: McGraw-Hill.

Ekerete, P. P. (2005). Industrial Marketing. Theory and Practice. Owerri: Springfield Publishers.

Hambagda, D. A. (1985). Buying: The decision making process in Nigeria's public sector-a preliminary investigation. In E. T. Inanga (Ed.), Managing Nigeria's economic system: A book of readings (pp. 46-58). Lagos: Heinemann.

Hutt, M. D., \& Speh, T. W. (1998). Business marketing management; A strategic view of industrial and organizational markets. Florida: The Dryden Press.

Kortge, G. D., \& Okonkwo, P. A. (1993). Perceived value approach to pricing. Journal of Industrial marketing management, 22(July), 133-140.

Lanani, R. A. (2005). A strategic approach to industrial product pricing; The pricing plan. Industrial marketing management, 34(2), 177-183. http://dx.doi.org/10.10169/j.imdmrmam.2004.07.015

Nagle, T. T. (1987). The strategy and tactics of pricing: A guide to profitable decision making. Englewood Cliff: Prentice Hall.

Noble, P. M., \& Gruca, T. S. (1999). Industrial pricing: Theory and managerial practice. Marketing science, 18(3), 435 - 454. http://dx.doi.org/10.1287/mksc. 18.3 .435

Qualls, N. J., \& Rosa, J. A. (1995). Assessing industrial buyer perception of quality and their effect on $\begin{array}{llll}\text { satisfaction. Industrial marketing } & \text { management, }\end{array}$ http://dx.doi.org/10.1016/0019.8501(95)00027-8.

Richeson, Lackey, C. W., \& Tarner, Jr., J. W. (1995). The effect of communication on the linkages between manufacturers and suppliers in Just-in-time environments. International Journal of Purchasing and materials management, 15(Winter), 21-29.

Shapiro, B. P., \& Jackson, B. B. (1978). Industrial Pricing to meet customer needs. Harvard Business Review, 56(November/December), 125-132. 